\title{
LEAVING THE HART-FULLER DEBATE AND RECLAIMING FULLER: FORM, AGENCY, AND MORALITY IN KRISTEN RUNDLE'S FORMS LIBERATE
}

\author{
Mark Bennett*
}

\begin{abstract}
Kristen Rundle's Forms Liberate: Reclaiming the Jurisprudence of Lon L Fuller provides an excellent analysis and re-interpretation of Fuller's legal theory. Its particular strengths are its comprehensive contextualisation of Fuller's famous arguments about the 'internal morality of law' within a wider project of 'eunomics' - the inquiry in the principles of good social order - and its reorientation of our view of Fuller's thought through his key idea of human agency. This review article sets out Rundle's main claims, and then challenges the argument that HLA Hart's responses to Fuller make him primarily responsible for the neglect and misunderstanding of Fuller's wider project in contemporary legal philosophy.
\end{abstract}

\section{INTRODUCTION}

After being outshone as the leading light in contemporary natural law or anti-positivist jurisprudence in the final decades of the 20th century by the blinding intensity of the work of the late Ronald Dworkin, Lon L Fuller's legal philosophy has enjoyed a resurgence of interest and comment in the last 10 years or so. Not only have we seen a number of important discussions of the Hart-Fuller debate on the 50th anniversary of its publication in the 1958 edition of the Harvard Law Review, ${ }^{1}$ but Fuller's articulation of the idea of the rule of law or legality has emerged as central to contemporary anti-positivism, and also to the theoretical foundations of 'common law constitutionalism' in England

* Lecturer, Faculty of Law, Victoria University of Wellington. I wish to thank, subject to the usual disclaimer: Joel Colón-Ríos, Grant Morris, and an anonymous reviewer for comments on drafts of this paper; David Dyzenhaus for many discussions of the subject matter covered; and Kristen Rundle for discussion and debate when we both gave presentations on this subject to the same legal philosophy course. This analysis draws on my recent doctoral thesis "Legal Positivism and the Rule of Law: the Hartian Response to Fuller's Challenge" available at <http://hdl.handle.net/1807/35776>.

1 Peter Cane (ed) The Hart-Fuller Debate in the Twenty-First Century (Hart, Oxford, 2010); "The Hart-Fuller Debate at Fifty: Symposium" (2008) 83 NYULR 993. 
and the commonwealth. ${ }^{2}$ Fuller is now ascendant: his work is the starting point for contemporary discussions of the rule of law; there is now a distinct school of Fullerian rule of law anti-positivism that vies with legal positivist approaches to both the nature of law and legal validity; and there is a developing tradition of constitutional theory based on that approach.

But despite the ascendance of Fuller's thought in these domains, there is still a sense within legal philosophy that his thought is marginal as opposed to mainstream. In her recent monograph on Fuller - Forms Liberate: Reclaiming the Jurisprudence of Lon L Fuller - Kristen Rundle argues that he was an "outsider within the intellectual climate of mid-twentieth century legal philosophy", who "remains mostly known as the natural lawyer who apparently lost the debate about the connection between law and morality" and whose work is thus seen as offering "little to enlighten the enduring debates of the discipline". ${ }^{3}$ How can this be, given the resurgence of interest in and support for Fuller's ideas noted above?

The reason is that it is the framework of thought of analytical legal positivism, set out most influentially in the work of HLA Hart, that seems to dominate 'general jurisprudence' - the inquiry into the nature of law. Although to demonstrate this idea by tracing the history of the subject is a difficult task, this impression of the centrality of Hart's positivism and the consequent marginality of Fuller's anti-positivism may be supported by noting that much of the activity in legal philosophy in the last 40 years has been the development, by a number of prominent thinkers, of broadly Hartian responses to Fuller and Dworkin's challenges (not to mention the ink spilled arguing about the merits of inclusive and exclusive versions of positivism).

In just this vein, NE Simmonds recently argued that criticism of contemporary legal theory can focus on Hart's concept of law, which "played such a large part in establishing the basic categories and assumptions in terms of which jurisprudential debate is now generally constructed". ${ }^{4}$ The view shared by Simmonds and Rundle is that Hartian positivism is the assumed starting point for inquiry into the nature of law, with Fuller's thought being commonly seen as an ineffective anti-positivist alternative that nevertheless contains some insights concerning the ideal of the rule of law. This is confirmed by Scott Shapiro's recent book Legality, which develops a legal positivist 'planning theory of law' broadly in the Hartian tradition. ${ }^{5}$ Shapiro's argument provides a detailed analysis of the key positions in contemporary legal philosophy, including a long discussion of Ronald Dworkin's

2 For example, in the work of TRS Allan Constitutional Justice (Oxford University Press, Oxford, 2003); David Dyzenhaus Hard Cases in Wicked Legal Systems: Pathologies of Legality (2nd ed, Oxford University Press, 2010) and The Constitution of Law: Legality in a Time of Emergency (Cambridge University Press, Cambridge, 2006); NE Simmonds Law as a Moral Idea (Oxford University Press, Oxford, 2008).

3 Kristen Rundle Forms Liberate: Reclaiming the Jurisprudence of Lon L Fuller (Hart, Oxford, 2012) at 1.

4 Simmonds, above $\mathrm{n} 2$, at 4 .

5 Scott Shapiro Legality (Harvard University Press, Cambridge (Massachusetts), 2011). 
position; but it discusses Fuller only at the end of the argument, where Shapiro treats Fuller as having provided some observations about the rule of law's value that support the planning theory but whose anti-positivism is fundamentally mistaken. ${ }^{6}$

That is the intellectual situation that Rundle seeks to address by reclaiming Fuller's ideas from the conceptual strait-jacket of positivist-dominated legal philosophy. Contrary to claims that Fuller's work was largely unsystematic and often confused and plainly wrong, Rundle's discussion of Fuller's arguments shows them to be coherent and powerful, forming an eminently suitable foundation for the schools of thought that he has influenced. Because of its careful, insightful, and clear analysis, Forms Liberate will become the standard point of call for anyone wanting to understand Fuller's project and thought.

This review article will attempt to set out the main lines of argument and contributions to our understanding of Fuller that Rundle makes in Forms Liberate, and will provide a minor criticism concerning the overall portrayal of the course of the Hart-Fuller debate. In particular, the language of 'reclaiming' is - at least to my mind - inapt, due to the historical progress of the debate and the positions that Hart put forward. As I will show, Rundle seeks to reclaim Fuller's thought from the grips of a debate about the connections between law and morality that was conducted on Hart's terms - the framework of analytical legal philosophy. But a close reading of that debate reveals that Hart was reluctant to make much of his differences with Fuller, and arguably did not deny that conformity to Fuller's principles of legality were of moral value. This is significant, because it is the point of difference that seemed to most infuriate and perplex Fuller, and which consumed much of Fuller's intellectual energy in response. As I will claim below, Fuller's fixation with these points was arguably a strait-jacket of his own making. If this admittedly unorthodox interpretation of the debate is accepted, then the shifting of our focus back to Fuller's main project from a situation that was largely of Fuller's own making does not seem to be a 'reclaiming' of his project at all, except in the sense that we might reclaim that project from Fuller himself. This may be merely a minor point of perspective and emphasis; but given that the tracing of the intellectual trajectory of Fuller's project and reception is a key part of Rundle's argument, it is worth raising the doubts that may be cast on it.

\section{FULLER'S 'RULE OF LAW' ANTI-POSITIVISM}

Fuller's theory of law was never stated as clearly as it might have been, but the main contours of his position are relatively well known - primarily through his book The Morality of Law and the extended discussion of the principles of the 'internal morality of law' that he identifies as central to his critique of legal positivism.

In The Morality of Law and elsewhere Fuller argues that the positivist vision of law as merely the system of rules created by an all-powerful sovereign or state fiat is misleading; instead, law should be

6 Shapiro, above n 5, at ch 14. 
seen as a "purposeful enterprise" that can only proceed on the basis of reciprocal expectations on the part of the government and ordinary citizens. ${ }^{7}$ Citizens will only have reason to engage in the activities and dispositions necessary for a legal order to exist if the law-giver abides by certain moral principles. Therefore, we cannot separate an understanding of the existence of law from an examination of "the purposive effort that goes into the making of law and the law that in fact emerges from that effort". ${ }^{8}$ An adequate concept of law must give both a normative account (an evaluation of moral foundations) and a sociological account (identification of the actual reasons of citizens and rulers) of the moral norms and understandings that constitute the reciprocal relationship underpinning the law and sustaining its power and authority. This is necessary because jurisprudential accounts of law must recognize "that maintaining a legal system in existence depends upon the discharge of interlocking responsibilities - of government toward the citizen and of the citizen toward the government." 9

It is this social reality of the relationship between ruler and ruled that sustains the flourishing of legal systems, and the moral norms on which this relationship is based - the internal morality of law that is ignored by positivist concepts of law. As Fuller put it in his critique of The Concept of Law: ${ }^{10}$

while Hart recognizes in passing that there exists something that may be called an internal morality of the law, he seems to consider that it has no significant bearing on the more serious concerns of jurisprudence.

He restated this point in his 'reply to critics' of The Morality of Law: ${ }^{11}$

The positivist recognizes in the functioning of a legal system nothing that can truly be called a social dimension. The positivist sees law at its point of dispatch by the lawgiver and again at the point of its impact on the legal subject. He does not see the lawgiver and citizen in interaction with one another, and by virtue of that failure he fails to see that the creation of an effective interaction between them is an essential part of law itself.

Put differently, the positivist concept of law therefore simply does not contain the kinds of inquiries that are necessary to adequately explain legal order: they are blind to the internal morality of law.

7 Lon L Fuller The Morality of Law (Revised ed, Yale University Press, New Haven (Connecticut), 1969) at 145 .

8 At 193 . See the very similar formulation earlier: "on the order imposed by law in abstraction from the purposive effort that goes into creating it" at 107; see also 117-118.

9 At 216 and also $138-140$.

10 At 155 .

11 At 193. 
Those with familiarity with jurisprudence will know what Fuller is pointing to by referring to the 'internal morality of law' and 'legality': these are just different ways of labelling the requirements of the rule of law, which identify the principles or desiderata that law must live up to if it is to achieve its purpose of "subjecting human conduct to the governance of rules". ${ }^{12}$ They will also know that he illustrated his argument with the tale of the hapless King Rex, who through his failure to conform to the basic principles of law-making, failed to make law at all. ${ }^{13}$ Through King Rex's inept example, we see that laws must be: ${ }^{14}$

(1) general; (2) [promulgated]; (3) prospective, not retroactive; (4) clear and understandable; (5) free from contradictions; and they should not (6) require what is impossible; (7) be too frequently changed; finally

(8) there should be congruence between the law and official action.

The moral importance of conformity to these principles may seem obvious, and Fuller himself only discusses it much later in his book. He emphasises that this 'morality of law' is different from classical natural lawyers' identification of substantive moral principles - which identified the values by which people ought to live their lives and what duties they owed to each other - but that it nevertheless does have a moral element, as revealed in his famous observation that while: ${ }^{15}$

legal morality can be said to be neutral over a wide range of ethical issues[, i]t cannot be neutral in its view of man himself. To embark on the enterprise of subjecting human conduct to the governance of rules involves of necessity a commitment to the view that man is, or can become, a responsible agent, capable of understanding and following rules, and answerable for his defaults. Every departure from the principles of law's inner morality is an affront to man's dignity as a responsible agent. To judge his actions by unpublished or retrospective laws, or to order him to do an act that is impossible, is to convey to him your indifference to his powers of self-determination.

So for Fuller the moral value that conformity to the rule of law secures is respect for human autonomy - for their dignity as self-determining agents - and it does so by restricting the scope of government interference to intelligible rules laid out in advance.

Of course, Fuller's distinctive claim is that these eight principles of the rule of law are not only morally valuable, but that they are central to the very idea of law, because they specify the "indispensible conditions for the existence of law at all". ${ }^{16}$ The rule of law principles constitute the central and inherent standards for the legal enterprise that the law-giver must give effect, if she is to

12 At 106, and also 122-130.

13 At $33-38$

14 As stated by HLA Hart Essays in Jurisprudence and Philosophy (Clarendon Press, Oxford, 1983) at 347.

15 Fuller, above $\mathrm{n} 7$, at 162

16 At 41 . 
play her role in creating a legal order: it is the moral standard of legality to which putative legal orders must conform, and which they must always strive to better instantiate. Fuller's claim is that we cannot properly understand law if we separate it from the ideal of the rule of law: the relationship is really one of equivalence, for the rule of law and law are just different ways of talking about the same idea.

\section{FULLERIAN ANTI-POSITIVISM TODAY}

This anti-positivist position, arguing for an inseparability of our concept of law from the ideal of the rule of law, is evident in the work of a number of prominent recent theorists such as TRS Allan, David Dyzenhaus, and NE Simmonds - each of whom acknowledges the influence of Fuller's thought. This is part of the resurgence of Fuller's anti-positivism noted above, and it challenges legal positivism to provide a morally-charged account of law and legal validity that shows how "the basic values of human dignity and individual autonomy" are intrinsic to law, so that "[1]egal obligation is ... a species of moral obligation" and the identification and interpretation of legal content is always dependent on our understanding of the rule of law. ${ }^{17}$ The rule of law should be understood as a key principle or doctrine underlying the fundamental rules of legal order, and should be given effect in determining legal obligations, ${ }^{18}$ "the judicial task is one of fidelity, not to a rule of recognition, but to the idea of law itself". ${ }^{19}$ For Fullerians, this obligation is both legal and moral: ${ }^{20}$

An official or citizen who believes that he has a moral obligation to obey the law, as the law of his society, made and enforced by legal institutions whose legitimacy he accepts, must reject as law - deny the legally

obligatory character of - rules whose iniquity places them beyond the constitutional bounds that his allegiance to the law implies.

It is not just that the rule of law is an ideal against which we should hold the law: its principles are "necessarily embedded in the law" so that it is always part of judge's legal obligation to uphold them, because "[n]ot only ... are such principles legal as well as moral; they are also, as it were, the constitutional principles of any legal order. ${ }^{21}$ So when a judge confronts an order or rule that derogates from legality, he is not just faced with an immoral rule, but "a legal pathology". ${ }^{22}$ For the Fullerian view of legality is: ${ }^{23}$

17 Allan, above n 2, at 6.

18 Allan, above n 2, at 218 and 75-76; Dyzenhaus Hard Cases, above n 2, at 167-168 and 251; Simmonds, above $\mathrm{n} 2$, at 157 .

19 Simmonds, above n 2, at 157.

20 Allan, above n 2, at 218.

21 Dyzenhaus Hard Cases, above n 2, at 251.

22 At $167-168$.

23 At 173 . 
the idea that there are principles ... immanent in legal order towards which judges and other legal officials must adopt an internal point of view. These principles are normative in that they must be accepted by judges and other legal officials as authoritative, as the correct standards to adopt in determining what counts as the law of their legal order. In other words, law is such when and only when it is legal - that is, it complies with the requirements of legality. The law of a legal order is thus the law determined in accordance with such requirements, which will include both the requirements of legality that any legal order has to instantiate, and the more contingent requirements that come out of that legal order's particular history.

Fullerian anti-positivists admit that theorists will differ on the political conception of law - the ideal of fidelity to law - that determines their theory of adjudication. ${ }^{24}$ But a full or complete account of law must include all of these features.

This Fullerian 'rule of law' anti-positivist theory has been applied to a number of different legal situations. Fuller himself, and Rundle in her discussion and elsewhere, applied the theory to Nazi Germany. ${ }^{25}$ TRS Allan has argued that it is applicable in a number of public law contexts, to show how judges ought to decide cases concerning the right to a fair trial, ${ }^{26}$ freedom of thought and speech, ${ }^{27}$ the abridgement of rights by the executive or the legislature, ${ }^{28}$ civil disobedience, ${ }^{29}$ and equality under the law, ${ }^{30}$ and a variety of aspects of judicial review. ${ }^{31}$ Dyzenhaus has shown how it should have been - and was sometimes - used by lawyers and judges in South Africa to resist Apartheid, ${ }^{32}$ and how it bears on legal decision-making relating to the state's responses to terrorism. ${ }^{33}$

\section{THE CLAIMS OF FORMS LIBERATE}

These recent returns to Fuller's challenge to legal positivism makes a rigorous re-examination of his jurisprudential project highly desirable, and thus Rundle's monograph is most welcome. By

24 At 172

25 Lon L Fuller "Positivism and Fidelity to Law: A Reply to Professor Hart" (1958) 71 Harv L Rev 630; Rundle, above $\mathrm{n} 3$ at 66-78; Kristen Rundle "The Impossibility of an Exterminatory Legality: Law and the Holocaust" (2009) 59 UTLJ 65.

26 Allan, above n 2, at 42-46 and 77-87.

27 At 89 and following.

28 At $47-50$.

29 At $92-106$.

30 At $121-125$ and $148-160$.

31 At ch 6.

32 Dyzenhaus Hard Cases, above n 2.

33 Dyzenhaus The Constitution of Legality, above $\mathrm{n} 2$. 
providing a detailed, well-argued and lucid discussion of Fuller's jurisprudence, the book establishes her as one of the most important contemporary anti-positivists working out of the Fullerian tradition.

As already noted, Rundle's aim is to affirm Fuller's jurisprudence as a still vital challenge to the dominant Hartian position. Drawing not only on the full gamut of Fuller's published writings but also on the archive of his unpublished papers and letters, Rundle's study attempts to reclaim Fuller's thought from the usual narrative and framework that she detects in mainstream legal philosophy, and especially in legal positivist discussions of Fuller's arguments. The received wisdom, she argues, sees Fuller as the loser in his debate with Hart, the progenitor of contemporary analytical legal philosophy. Fuller is cast as a lively but unclear thinker whose valuable exposition of the principles of the rule of law could not live up to his aim of demonstrating the existence of an internal morality of law - a necessary moral element in the law that vindicates a more 'natural law' perspective.

Forms Liberate seeks to show that while such an understanding of Fuller is natural for legal positivists, who are intent on forcing Fuller's insights through their own philosophical framework, it is contrary to the actual project Fuller was engaged in, meaning that Fuller's significant contributions to our understanding of law remain neglected. This is why her own project of reclaiming Fuller is so important: it should not be for his opponents to set the agenda for Fuller's contribution to jurisprudence, and we will only benefit from his perspective if we understand his theory as answering the questions he himself sought to answer, through the methods of inquiry that he thought relevant to that task.

The first task is therefore to understand the questions that drove Fuller's project, and hence the central move Rundle makes to reclaim Fuller is to orient the reader to approach Fuller from an "underexplored angle", namely "his interest in the connection between the form of law and its relationship with human agency." ${ }^{34}$ The 'form of law' refers to the particular means and structures by which the law regulates human conduct - its "distinctive mode of creating and communicating norms" - including Fuller's famous account of the eight principles of the rule of law. ${ }^{35}$ That Fuller's jurisprudence should be primarily understood as concerned with elucidating the connection between form and agency is of Rundle's central claims. Her sustained, detailed, and precise exegesis of Fuller's work make it highly likely that the reader will be convinced that: ${ }^{36}$

a proper understanding of Fuller's jurisprudence requires that we begin with his enduring interest in the distinctiveness of law's form, and then, from this starting point, witness how he proceeds to interrogate the implications of that form for the character, existence, and normativity of law, and, indeed, for the enterprise of legal philosophy itself.

34 Rundle, above $\mathrm{n} 3$, at 2.

35 At $2-3$.

36 At 2. 
While Fuller's concern for the formal or procedural elements of law has been well commented on over the years, ${ }^{37}$ Rundle's analysis rivals - and perhaps even surpasses - these in its depth of analysis, providing a faithful synthesis and restatement of Fuller's project.

One of Rundle's other key claims is that the reason that mainstream legal philosophy has lost touch with Fuller's main concerns is that too many discussions of his arguments detach bits off his wider project - these bits being, primarily, his account of the eight principles of the rule of law and his related debates with Hart - in order to defuse Fuller's critique or simply to appropriate them for their own purposes. In other words, Fuller is often used merely as a means of developing the Hartian positivist concept of law.

Rundle's response is that to properly understand Fuller's project we must see that he is not tinkering with or criticising the positivists' concept of law from within, but opposing that concept with his own anti-positivist view of law: ${ }^{38}$

For Fuller, there can be no meaningful concept of law that does not include a meaningful limitation of the lawgiver's power in favour of the agency of the legal subject. This is not a moral objective that is imposed on the enterprise of lawgiving from without. It is, rather, simply something that follows from the formal distinctiveness of law as the enterprise of subjecting human conduct to the governance of general rules.

While Fuller was reluctant to use the title 'natural law' due to its associations with the higher law arguments of the classical natural law tradition, ${ }^{39}$ he recognised that he stood opposed to positivism due to his casting of law as an intrinsically moral phenomenon. ${ }^{40}$ As Rundle explains, Fuller thought that: ${ }^{41}$

when we take seriously the idea that law finds expression through a distinctive form, we come to see that to create and maintain that form requires the adoption of a distinctive ethos, a special understanding of the demands of his role, on the part of the lawgiver. Law is thus intrinsically moral in the sense that it is constitutively dependent on the observance of this ethos. ... [A] key part of the demands of this ethos [is that] law is also intrinsically moral for how its form - that of governance of general rules - presupposes the legal subject's status as a responsible agent. Thus, law is also intrinsically moral for how, if it is to function, it must maintain and communicate respect for that status of agency.

37 Robert Summers Lon L Fuller (Stanford University Press, Stanford (California), 1984); Kenneth Winston "Introduction" in Lon L Fuller The Principles of Social Order: Selected Essays of Lon L Fuller (Revised ed, Hart Publishing, Oxford, 2002); Jeremy Waldron "Why Law - Efficacy, Freedom or Fidelity?" (1994) 13 Law and Philosophy 259.

38 Rundle, above $\mathrm{n} 3$, at 2.

39 Fuller The Morality of Law, above n 7, at 96.

40 Rundle, above $\mathrm{n} 3$, at 3.

41 At 3 . 
Rundle claims that Fuller's understanding of law has been obscured by the tendency in recent and contemporary legal philosophy to read Fuller's claims as answering the question of "whether the fact of something being law guarantees the moral status of the ends pursued through it". ${ }^{42}$ This prism of analysis has concealed the vision of law outlined in the quotations above, and Rundle's book ably redresses the balance by providing a meticulous and powerful restatement and reinterpretation of Fuller's conception of law.

In doing so, Rundle desires to reclaim Fuller's jurisprudential project from the grips of the Hartian agenda into which it first fell into during the 1958 Hart-Fuller debate in the Harvard Law Review. ${ }^{43}$ In part, this is a matter of freeing Fuller from the "agenda-setting force of the vocabulary of analytical legal philosophy". ${ }^{44}$ But, more importantly, it is a matter of focussing on Fuller's own concerns and the tentative answers he provided to questions about the relationship between law's form and human agency - his theory of 'good order' or eunomia ${ }^{45}$ - that is the key to reclaiming his thought.

\section{FULLER'S EUNOMICS}

Fuller's eunomics was the search for the rational principles of good social order that formed a (more or less) objective 'natural law' of structuring people's relationships with one another. ${ }^{46}$ In the sceptical intellectual/academic climate of the early 20th century, Fuller knew any reference to objective morality would seem like just one more version of the 'higher law', but he focussed on fundamentals of human interaction embedded in our legal concepts. ${ }^{47}$ This project was announced in an early essay on the state of American jurisprudence, in The Law in Quest of Itself, and found some expression in his readings and written materials produced for his jurisprudence course. ${ }^{48}$ It aimed to "move the agenda of legal philosophy ... towards questions relating to the form, limits and opportunities for agency afforded by different modes of social ordering". ${ }^{49}$

This project was clearly unfinished; Fuller was only able to produce an unsystematic - but fertile - set of observations about different kinds of social order, without developing them into any grand

42 At 3

43 At 5 .

44 At 6

45 At 32.

46 Rundle, above n 3, at 43.

47 Fuller, above n 7, at 96-97.

48 Rundle, above n 3, at 35. Fuller's project is found in Lon Fuller The Law in Quest of Itself (Foundation Press, Chicago, 1940); Lon Fuller Problems of Jurisprudence (Foundation Press, Mineola (New York), 1949).

49 Rundle, above n 3, at 49. 
scheme. However, in the face of commentators who revolt against the attempt to identify systemic themes in Fuller's thought, Rundle shows that there is a "coherent jurisprudential vision". 50

But how exactly should we understand the eunomical project? Rundle describes it at one point as a foray into a jurisprudence considered as "intuitive wisdom about law", ${ }^{51}$ namely a wisdom concerning the forms, relationships and commitments which different processes within the law must aspire to take if they are to best fit with fundamental and widely shared human aims for the law. In particular, it considers how legal form can be best structured so as to respect human agency, and how this idea of legal form is inherent in our ordinary understandings of law - our concept of law itself. ${ }^{52}$

This project sought to free jurisprudence as Fuller perceived it in the 1930s from the grips of both legal positivism and (positivistic) legal realism, which both ignored this ideal element in the law. As is clear in The Law in Quest of Itself, Fuller thought these to be arid theories of law, deliberately divorced from questions concerning what law ought to be, and thus with nothing to contribute to jurisprudence's real task of giving "a profitable and satisfying direction to the application of human energies in the law". ${ }^{53}$ Eunomics, Rundle insightfully observes, existed at two levels: as a general perspective on the possibility of bringing reason to bear on the question of what the law ought to look like - eunomics 'writ large' - and also the more detailed discussions of different mechanisms or forms of social ordering - eunomics 'writ small'. ${ }^{54}$ Fuller was acutely aware that the idea of reason telling us what society ought to look like had fallen out of fashion in the early 20 th century intellectual life, ${ }^{55}$ and eunomics was his response: the search for and description of the ideals on which legal institutions should be based. Having read the relevant corpus of published writings, my impression is that Rundle's discussion of the project is faithful to Fuller while at the same time making his intentions and positions clear.

Thus, the book's second chapter provide an illuminating overview of Fuller's early attempts to show that jurisprudence should aim to answer the normative questions inherent in the very form of law. Fuller's confidence that such inquiry was profitable went along with an understanding that framing the inquiry in the classical natural law terms of a transcendent higher law went against the grain of contemporaneous jurisprudential and general philosophical thinking. ${ }^{56}$ Fuller's goal was to rehabilitate the idea that there are principles of social order that allow individuals with differing goals

50 At 17

51 At 11 .

52 At $9-10$.

53 Rundle, above n 3, at 25. Quote is from Fuller The Law in Quest of Itself, above n 48, at 2.

54 Rundle, above $\mathrm{n} 3$, at 26.

55 Fuller The Law in Quest of Itself, above $\mathrm{n} 48$, at 120-127.

56 Rundle, above $\mathrm{n} 3$, at 30. 
and interests to live together and be autonomous agents - principles that make 'reducing the relations of men to a reasoned harmony" an intelligible task for jurisprudence ${ }^{57}$ - a project Fuller thought got off to a useful start in Aristotle. ${ }^{58}$ The project of eunomics is set out with clarity, detail, and insight in the rest of the chapter, with Rundle showing how Fuller thought that eunomics was not only necessary as an aspirational project, but also as an account of the fundamental normative baselines upon which any legal order must be built if it is to maintain the respect of its subjects and flourish on the basis of their reciprocal support. ${ }^{59}$ As Fuller emphasised throughout his work, eunomics was a theory of good order that was neutral amongst most substantive ends: it did not, like traditional natural law, close off particular moral or political viewpoints and their expression in legal rules by saying that some positions could simply not be law at all; instead it sought to uncover the natural laws of social ordering that must underlie any attempt to govern human conduct if social order is to be "workable, effective, and respectful of human dignity". 60

Fuller's jurisprudential project of eunomics was therefore a kind of natural law that took means seriously'. Rather than specifying some unchallengeable or objective substantive ends that the law must give effect to, like traditional natural law, he sought to specify the natural law of means. This would be achieved by examining how the various forms of social order by which we attempt to live a life in common can be best structured, where 'good' looks back to basic questions of workability and human autonomy and dignity. ${ }^{61}$ Rundle sums up this position by observing that: ${ }^{62}$

Fuller's jurisprudence is best reclaimed through the prism of his understanding of the connections between the distinctive form of law and human agency. ... Fuller's jurisprudence is animated by an understanding of form that is inclusive of the legal subject's presupposed status as a responsible agent. There is not a form called law that acts upon the legal subject, but rather, the form of law includes the legal subject's capacity for agency within it.

Rundle proceeds to provide an analysis of Fuller's eunomics writ small in particular modes of social ordering - adjudication, custom, legislation, contract, mediation etc. The main insights she draws from this analysis are the distinctiveness of each form of social ordering, both in terms of basic features and how the moral imperative of human agency justifies those features. ${ }^{63}$ The discussion Fuller provides of these different forms of social ordering demonstrates, Rundle claims, the

57 Fuller The Law in Quest of Itself, above n 48, at 3.

58 Rundle, above $\mathrm{n} 3$, at 30 .

59 At 33.

60 At 34.

61 Rundle, above n 3, at 36.

62 At 38.

63 At 40-41. 
fundamental interest Fuller had in the relationship between form and agency both in terms of theoretical insights about the nature of law as a social enterprise, and also by reference to "the everyday experience of how legal processes are constituted and enlivened by the ways in which agents participate within them."64

\section{PUTTING FULLER'S THOUGHT BACK INTO CONTEXT}

Fuller's eunomical project was sweeping in its goals and has resonances today with a number of theoretical inquiries into the best forms of social ordering. Yet in jurisprudence textbooks, Fuller is usually not portrayed as a theoretician of eunomics, but as presenting a 'modern' kind of natural law theory that seeks to unseat Hart's legal positivism as the dominant position in Anglo-American jurisprudence. Why is this? As we have already seen, Rundle claims that Fuller's place in the jurisprudential canon is due to the framework imposed by his debate with Hart, from the Hart-Fuller debate onwards. She argues that Fuller accepted Hart's agenda for the debate, and the mainstream assessment of who won the debate - namely, Hart - has to an "enormous extent" shaped the reception of Fuller's work in jurisprudence. ${ }^{65}$

In setting out this argument, Rundle's third chapter recounts the arguments made by Hart in his famous Holmes lecture and those made in reply by Fuller. Her analysis of what Fuller is trying to do to get Hart to accept there is a normative foundation for law's existence, that this foundation is the rule of law, and the moral difference that it makes for human agency - is portrayed as going beyond the question that Hart is attempting to deal with: whether there is some kind of conceptual separation of law and morality. ${ }^{66}$ The discussion is characteristically rich, and powerfully contextualises Fuller's arguments in his debate with Hart in relation to his wider eunomical project. Rundle's separate discussion of the Nazi Germany example makes clear the difference in perspective between Fuller and Hart. ${ }^{67}$

Despite the influence of his 1958 debate with Hart, it is probably his monograph The Morality of Law, which contains the famous allegory of King Rex and the elaboration of the eight principles of legality or the rule of law that Fuller is still best known for. The fourth and fifth chapters of Forms Liberate provide similarly detailed, clear, and insightful analyses of Fuller's statements of not only his position in The Morality of Law, but also of Fuller's 'Reply to Critics' (added to the revised edition), and of the responses that his work drew from Hart. Again, Rundle's conclusions are that Hart's responses to Fuller: ${ }^{68}$
64 At 42
65 At 52 .
66 Rundle, above $\mathrm{n} 3$, at ch 3 .
67 At $66-78$.
68 At 87. 
had the effect of settling the dominant interpretation of Fuller's jurisprudence and its widespread evaluation as an unsuccessful rejoinder to positivism on the matter of the necessary separability of law and morality.

Hart's responses narrowed the terms of the debate down from the expansive concerns of eunomics to the old jurisprudential 'chestnut' of whether there was anything inherently moral about law, which positivists are supposed to answer by saying 'no - there is no necessary connection between law and morality'.

One of the most important aspects of this discussion, which distinguishes it from other examinations of these well-worn ideas, is how Rundle sets out Fuller's claims within the context of her thesis that Fuller's thought has been misrepresented by being read through the lens of analytical legal positivism. Against the background of her argument and the discussion of eunomics in Chapter 2, Rundle's analysis of the later rounds of Fuller's debate with Hart gives us a better sense of the context of the particular claims Fuller makes about King Rex and the eight principles of legality. By doing so, she illuminates the foundations and concerns of a number of particular arguments and significant swathes of The Morality of Law that must seem mysterious to those that come to that text by way of the usual jurisprudential textbooks, which obscure that wider project. Rundle's evident confidence that a proper understanding of Fuller's jurisprudence demanded a further, book-length analysis is demonstrated to be well grounded, for it is only by looking at his thought as a whole that we can see what Fuller was really up to: the concerns, themes, and arguments that recur throughout his work and which lend it a coherence that is often not appreciated.

Read in its proper context, we see Fuller's most famous work not as an overlarded set of mixed insights around a key claim in legal philosophy - that the rule of law marks out the necessary moral element of law - but as an integral part of the project of reflecting on how to make the law good, in one particular element of the law's distinctive forms of social ordering. Rundle's analysis over these chapters convincingly backs up her claim that we ought to reconsider the textbook presentation of Fuller and return to his eunomical insights, and in the course of doing so she provides some of the most full and interesting discussions of a number of Fuller's arguments, including his conception of the person as a responsible agent implicit in legality, ${ }^{69}$ and the idea of trusteeship of or fidelity to legality. ${ }^{70}$ These analyses are supplemented by her use of the archive of Fuller's papers to show how Fuller stated some of his key positions more stridently in private. At the end of the middle chapters concerning Fuller's engagement with Hart, we are left with Rundle's clear statement of the core claims of Fuller's jurisprudence. ${ }^{71}$

69 Rundle, above n 3, at 97-101.

70 At $105-115$.

71 At $139-140$. 


\section{ASSESSING THE CULPABILITY OF HARTIAN POSITIVISM I: THE CAPTURING OF THE AGENDA?}

Despite the power of Rundle's analysis and her argument in general, one thing that should be queried is the culpability of Hart and his Hartian positivist descendants in obscuring Fuller's insights. Rundle argues that Fuller was drawn into a debate with Hart and other legal positivists in which Hart set the agenda, and that Fuller never broke free from articulating his ideas in response to that framework, and has been understood in this way by legal philosophers, or at least legal positivists, ever since. ${ }^{72}$ That observation is fine as far as it goes, but how far does it really take us? Thinkers will always look at an idea from the perspective of their own intellectual concerns, and take from it what is useful - or will criticize it in comparison with their own ideas - from the perspective of and for the purposes of their own projects. If Fuller's legal theory and its wider project of eunomics gets short shrift from legal positivists, that is because they do not find it a compelling objection to their way of thinking about law. What they do find important is Fuller's principles of legality, and they incorporate those principles into their legal theories in various ways, again from their legal positivist perspective rather than Fuller's.

While that means that Fuller's perspective is not dealt with in any detail by Hart, Raz, or other contemporary legal positivists, the criticism we should levy is that the positivist perspective is plainly wrong or that is has not adequately grappled with Fuller's wider challenge to their theory, rather than that positivists don't engage with Fuller's own projects. These things would cause problems for legal positivism if true, and whether positivism has adequately dealt with Fuller's wider concept of law is still a compelling question. ${ }^{73}$

But if Hart and other contemporary positivist are not minded to grapple with these issues, we must therefore expect that they will discuss Fuller only the terms of their own theories and concerns, rather than laying out Fuller's wider project in detail each time they discuss the rule of law. As Hart suggested in his review of The Morality of Law, his and Fuller's "starting points and interests in jurisprudence are so different that the author and I are fated never to understand each other's work" ${ }^{74}$ Hart never adequately explained his preference for his own account of law, except his view that his concept of law was a good explanation of 'our' understanding of law. And given that Fuller - and later Fullerians such as Rundle - insist that our concept or understanding of law is one that includes the rule of law and the particular relationship between the law-giver and legal subject that satisfies one aspect of the ideal of human autonomy, it is clear that an adequate refutation of Fuller would have to somehow show that Hart's concept is superior to Fuller's.

72 At 52 .

73 I have attempted to begin answering it in my recent doctoral thesis "Legal Positivism and the Rule of Law: the Hartian Response to Fuller's Challenge" available at <http://hdl.handle.net/1807/35776>.

74 Hart Essays in Jurisprudence and Philosophy, above n 14, at 343. 
How this might be done is a disputed matter. But ultimately Hart's fault is not that he does not engage in Fuller's project, but that he does not adequate show how his concept of law makes sense of our ordinary understandings of law as bound up with the idea of the rule of law and of human freedom. While Hart devoted many words to the latter, and some to the former, he denied that they were a central concern in explaining the concept of law. Fuller's challenge for positivism to show why the rule of law is not central to law still stands, and in fact a number of positivists - Gardner, Marmor, Kramer, Waldron - have discussed this question in some detail recently. ${ }^{75}$

However, contrary to the above line of thought, Rundle lays more blame for Fuller's place in the contemporary jurisprudential landscape on Hart than just in Hart's success in shaping the conversation. It was Hart's objection to Fuller's arguments concerning the rule of law's moral value that "was so decisive to Fuller's dismissal from the inner circle of twentieth century legal philosophy", ${ }^{76}$ and which meant that Fuller failed to become a successful, mainstream legal philosopher. Hart had undermined the supposedly moral element in the rule of law, thereby nullifying Fuller as a challenge to legal positivism, which was "the primary cause of his marginalisation from the inner circle of legal philosophy during his time". ${ }^{77}$ Hart, as Rundles observes, argued that: ${ }^{78}$

"Fuller gave us no meaningful reason to distinguish his 'internal morality of law' from an 'internal morality of poisoning': aided by the principles of efficacy reflected in the so-called internal morality of law, morality enters law only when this instrument is used for moral good. But beyond this, the argument ran, there is no meaningful sense in which those principles ought to be regarded as moral".

The success of this famous argument has had a "decisive impact" on the "scholarly memory" of Fuller's jurisprudence. ${ }^{79}$ Rundle claims that few legal philosophers - and even fewer legal positivists

75 John Gardner "The Legality of Law" (2004) 17 Ratio Juris 168; John Gardner "Introduction" in HLA Hart Punishment And Responsibility: Essays in the Philosophy of Law (2nd ed, Oxford University Press, Oxford, 2008); John Gardner "Hart on Legality, Justice and Morality" (2010) 1 Jurisprudence 253, available at <http://ssrn.com/abstract=1606463>; Matthew Kramer "Scrupulousness without Scruples: A Critique of Lon Fuller and His Defenders" (1998) 18 OJLS 235; Matthew H Kramer "On the Moral Status of the Rule of Law" (2004) 63 CLJ 65; Matthew H Kramer "On the Moral Status of the Rule of Law" (2004) 63 CLJ 65 at 85-86; Kramer In Defense of Legal Positivism, above n 49, at 69-70; Matthew H Kramer "The Big Bad Wolf: Legal Positivism and Its Detractors" (2004) 49 Am J Juris 1; Andrei Marmor "The Ideal of the Rule of Law" in Dennis Patterson (ed) A Companion to Philosophy of Law and Legal Theory (2nd ed, John Wiley \& Sons, Oxford, 2010); Andrei Marmor "The Rule of Law and its Limits" (2004) 23 Law and Philosophy 1. Jeremy Waldron "Why law - Efficacy, freedom, or fidelity?" (1994) 13 Law and Philosophy 259; Jeremy Waldron "Positivism and Legality: Hart's Equivocal Response to Fuller" (2008) 83 NYUL Rev 1135.

76 Rundle, above $\mathrm{n} 3$, at 11.

77 At 59 .

78 At $14-15$.

79 At 15. 
- have challenged Hart's argument, ${ }^{80}$ and that although Fuller never thought of his debate with Hart as revolving around the question, the "morality versus efficacy" prism has exercised a power over later interpretations of Fuller that cannot be overstated. ${ }^{81}$ Reclaiming Fuller's jurisprudence, therefore, requires that "his claims be extracted from a conversation that, at Hart's lead, pitted claims about law's 'morality' against ones about its 'efficacy'". ${ }^{82}$

The view that Fuller's reception has been affected by his debate with Hart is clearly correct. Hart's critique of Fuller has become famous in textbook discussions and jurisprudence texts, which are content to set out the basics of Fuller's eight principles of legality and the main criticisms. However, we should query whether Hart should bear much responsibility for this neglect and misunderstanding of Fuller's wider project in contemporary legal philosophy.

For one thing, the efficacy critique was a powerful counter to one of Fuller's claims made by a number of commentators at the time. ${ }^{83}$ But as Rundle's discussion of Fuller's wider project shows, there was much more to Fuller that did not hinge on the efficacy argument, and again the more important question is why jurisprudence has shifted so heavily towards Hart's project rather than Fuller's. While the development of intellectual traditions is difficult to trace out, the efficacy critique need not be seen as the main reason for the neglect of Fuller's project. It seems just as plausible that (i) the fact that Fuller's project could not be framed into a simple 'nutshell' critique of Hart's positivism, and rather was a completely contrary approach and agenda for legal thought, combined with (ii) the power and relative directness of Dworkin's anti-positivist challenge to Hart, and the rise of critical legal studies, meant that the 'exciting' debates in jurisprudence in the 1970s and 1980s had moved away from Fuller's challenge. It is unfortunate that Fuller did not see the recent resurgence of discussion of and support for his jurisprudential viewpoint, but it seems too much to say that Hart's dismissal of one key aspect of Fuller's arguments explains the neglect of Fuller's wider theory in the decades before and after his death.

The other reason for exculpating Hart as the major cause of Fuller's neglect is that Fuller's own understanding of, and focus on, Hart's efficacy critique may be the main reason for the lack of attention to Fuller's wider project. Rundle shows that Fuller was obsessed with the way that Hart made the efficacy argument, and how Hart played up Fuller's own acknowledgements of the rule of law's efficacy without noting Fuller's emphasis on the moral aspects of this. ${ }^{84}$ As Rundle's analysis of

80 At 15 .

81 At 15 .

82 At 193

83 Marshall Cohen "Law, Morality, and Purpose" (1965) 10 Villanova LR 640; Ronald Dworkin "The Elusive Morality of Law" (1965) 10 Villanova LR 631; Robert Summers "Professor Fuller on Morality and Law" (1965) 18 J Legal Educ 1.

84 Rundle, above n 3, at 105-108. 
Fuller's working notes for his 'Reply to Critics' shows, Fuller thought that Hart's omission of the idea of the law-giver's trusteeship of the eight principles obscured the moral value of compliance with those principles: "'H.L.A.H. cuts out the reference to trusteeship, and uses my reference to "the pride of craftsmanship" as a kind of admission by me that the whole thing is a matter of 'efficacy"'. 85

While anyone will be concerned at the misrepresentation of their views, Fuller must shoulder the bulk of the burden for focusing his debate on this question, which Hart dealt with only relatively briefly and under direct challenge from Fuller to his own project. Hart felt that his replies to Fuller were adequate for his own purposes; Fuller thought that his criticisms were misunderstood, that they threatened Hart's project more than Hart admitted, and sought to show why this was so by demonstrating how Hart had mistaken the critique. This constrained Fuller's ability to engage in his own project of eunomics, and influenced the way in which we remember his work. But if Fuller has been marginalised from the inner circle of legal philosophy, it is his response to Hart that was decisive, not Hart's response to him. Rundle acknowledges this, but there is implicit in the idea of 'reclaiming' Fuller a suggestion that Fuller's obsession with the efficacy/morality issue was Hart's doing, and not Fuller's - and this should be challenged.

\section{THE CULPABILITY OF HARTIAN POSITIVISM II: THE MORAL ARGUMENT?}

Furthermore, there is another wrinkle to add to the idea that we must reclaim Fuller's project from the hands of Hart's decisive criticisms, because it is not clear that Hart ever said that Fuller's principles were only a matter of efficacy - that there is nothing morally valuable about compliance with those principles. Put differently, it is arguable that Hart did not argue that conformity with Fuller's principles is of no moral value. ${ }^{86}$

This is an unorthodox suggestion, because the idea that Hart and other positivists answered Fuller by saying that Fuller's principles are only the requirements of efficacious law-making - effective guidance of human conduct by rules - is well entrenched in the jurisprudential literature. ${ }^{87}$ It is buttressed by the fact that Hart (and Raz and other positivists) did clearly say that the principles of the

85 At 107 .

86 See Gardner "Hart on Legality, Justice and Morality", above n 75 and Mark Bennett "Hart and Raz on the Non-Instrumental Moral Value of the Rule of Law: A Reconsideration" (2011) 30 Law and Philosophy 603.

87 See Brian Bix "Natural Law: The Modern Tradition" in Jules Coleman and Scott Shapiro The Oxford Handbook of Jurisprudence and Philosophy of Law (Oxford University Press, 2004) 81; David Dyzenhaus "Positivism's Stagnant Research Programme" (2000) 20 OJLS 703 at 722; Evan Fox-Decent "Is the Rule of Law Really Indifferent to Human Rights?" (2008) 27 Law and Philosophy 533 at 537 and 559-560; JW Harris Legal Philosophies (2nd ed, Oxford University Press, Oxford, 1997) at 148; Andrei Marmor "The Rule of Law and its Limits" (2004) 23 Law and Philosophy 1, at 38-39; Colleen Murphy "Lon Fuller and the Moral Value of the Rule of Law" (2005) 24 Law and Philosophy 239; Jennifer Nadler "Hart, Fuller, and the Connection Between Law and Justice" (2008) 27 Law and Philosophy 1 at 21; Simmonds, above n 2, at 45 and 54, fn 26; Robert S Summers Lon L Fuller (Stanford University Press, Stanford (California), 1984) at 37. 
rule of law identified by Fuller were things that made the guidance of human conduct by rules more effective. Hart's claim is that Fuller confuses efficacy in the pursuit of purposes with morality; this is the most important of Hart's criticisms of The Morality of Law. ${ }^{88}$ That is the point from Hart's review that has ever since been a staple of jurisprudence courses and textbooks, and it has spawned a significant literature in defence of Fuller. ${ }^{89}$

The problem is that in that literature Hart's point - that internal or purposive principles of efficacy are inaptly called 'a morality' - has almost always been interpreted as the claim that there is nothing of moral value that accompanies the fulfillment of those principles. ${ }^{90}$ In other words, Hart is most commonly interpreted as saying that this efficacy value is the only value associated with compliance with the rule of law - and that there is nothing of moral value that follows from such compliance. ${ }^{91}$ This view is furthered by Forms Liberate. After her detailed analysis of the positions of Hart, Rundle supports the orthodox view that Hart's response to Fuller's claims about moral value was that Fuller's principles "merely make the pursuit of purposes through law more effective"92 - that they are "merely principles of the lawgiving craft and nothing more"93 and having "nothing at all to do with morality". ${ }^{94}$

While this reflects the orthodox view on the proper interpretation of Hart's arguments, I think that the best interpretation of Hart is that he did not make such an argument. ${ }^{95}$ Hart's claim that Fuller's principles are not 'a morality' need not be taken as a denial that those principles are of moral value this does not follow, because Hart is not examining the moral value of conformity those principles at all. On this alternative interpretation Hart's criticisms, rather than denying any moral value, are directed only against what he sees as Fuller's view that these principles are a unique 'morality of law'a morality derived from the very idea of law itself.

That is the key 'purposive' point Hart is making: although Fuller is right to identify his eight principles as "forms of legal excellence", he is wrong to call these principles a morality, because they are actually: ${ }^{96}$

88 Rundle, above $\mathrm{n} 3$, at 103.

89 Murphy, above n 87; Nadler, above n 87; Simmonds, above n 2.

90 See especially Murphy, above n 87.

91 See especially Murphy, above n 87.

92 Rundle, above n 3, at 96.

93 At 103.

94 At 106.

95 See Bennett, above n 86.

96 Hart Essays in Jurisprudence and Philosophy, above n 14, at 347. 
derived, not from principles of justice or other "external" moral principles relating to the law's substantive aims or content, but are reached solely through a realistic consideration of what is necessary for the efficient execution of the purpose of guiding human conduct by rules. We see what they are by occupying the position of the conscientious legislator bent on this purpose, and they are essentially principles of good craftsmanship. Indeed, they are compared by the author to principles (he says, "natural laws") of carpentry. They are independent of the law's substantive aims just as the principles of carpentry are independent of whether the carpenter is making hospital beds or torturers' racks.

Because these principles are derived from reflection on how rules can more effectively guide human conduct, Hart thinks that to call them the 'internal morality' of law "breeds confusion", and therefore he prefers to adopt what he thinks is the more conventional designation - the "principles of legality". ${ }^{97}$

Hart therefore criticizes Fuller's failure to distinguish between purposive activity and morality: we should not call the set of internal principles that best allow an instrument or practice to achieve its purposes "a morality", for then we would have to accept that there was an internal morality of, say, poisoning. ${ }^{98}$ In other words, we should not confuse the existence of internal principles guiding the efficacious achievement of a purpose with morality. But the key point is that nothing in this argument denies that conformity to these principles is of moral value: the point is whence they came, not their value. The argument is simply not directed towards the moral value of the principles at all.

This interpretation is unorthodox, and the usual interpretation cannot be ruled out. But if the alternative interpretation is correct, then we need not accept that Hart denied the moral value created through compliance with Fuller's principles. And while the argument is unorthodox, it is not unique. John Gardner has argued that Hart recognized Fuller's principles as 'principles of justice' that allow for the maximization of "individual freedom within the coercive framework of law"'. 99 In Gardner's interpretation, Hart thought that: ${ }^{100}$

conformity with the rule of law... helps to protect people against law-enabled and law-facilitated oppression, against the various modes of unfreedom (such as heavy-handed policing, show trials, and the use of influence to get above the law) that the existence of a legal system otherwise tends to open up and encourage.

97 At 347.

98 At 350

99 Gardner "Hart on Legality, Justice and Morality", above n 75, at 11-13.

100 At 7. 
What then of Hart's review, and the rejection of Fuller's characterisation of the rule of law principles as 'a morality'? As Gardner explains, it is possible to interpret Hart as claiming that: ${ }^{101}$

the principles of the rule of law 'are not valued [by Hart] ... for their own sake.' ... He values them as instruments of maximal freedom against what would otherwise be the oppressive might of the law. And that - maximal freedom - counts as a 'moral aim' because freedom, unlike the rule of law, is presumably something that Hart does indeed value 'for [its] own sake'.

This is close to my favoured interpretation of Hart's argument as denying that the rule of law principles themselves form a morality, but accepting that conformity with those principles is valuable according to some actual moral scheme. While Gardner, like Waldron, finds Hart to be equivocal on these points, in the context of Hart's other writings the alternative interpretation is a plausible challenge to the orthodox one.

Indeed, when one closely examines all of the different things Hart said about the rule of law, both in his direct confrontations with Fuller and his other work, one sees the dual perspective, rather than the 'efficacy only' perspective, coming to the fore. Consider the following: ${ }^{102}$

- In The Concept of Law, Hart states that the moral value that the rule of law secures may be accepted as a necessary connection between law and morality: ${ }^{103}$

Plainly these features of control by rule are closely related to the requirements of justice which lawyers term principles of legality. ... Again, if this is what the necessary connection of law and morality means, we may accept it. It is unfortunately compatible with very great iniquity."

The great iniquity stands alongside the moral value created by conformity to the rule of law.

- In his review of The Morality of Law, Hart says that he values conformity to the rule of law principles due to its contribution to human happiness or autonomy. For example: ${ }^{104}$

the normal generality of law is desirable not only for reasons of economy but because it will enable individuals to predict the future and that this is a powerful contribution to human liberty and happiness

- In Punishment and Responsibility, Hart makes it clear that the value of one aspect of the rule of law - the requirement of intentional action that is inherent in the 'possibility' criterion - is

101 At 16.

102 Further analysis can be found in Gardner, above n 75 and Bennett, above n 86 .

103 HLA Hart The Concept of Law (2nd ed, Clarendon Press, Oxford, 1994) at 207.

104 Hart Essays in Jurisprudence and Philosophy, above n 14, at 356-357. 
of immense moral value in guaranteeing at least some kind of human autonomy, even in wicked regimes. ${ }^{105}$ He states that: ${ }^{106}$

[I]n South Africa, Nazi Germany, Soviet Russia, and no doubt elsewhere, we might be thankful to have [the laws'] badness mitigated by the fact that they fall only on those who have obtained a satisfaction from knowingly doing what they forbid.

- In an encyclopaedia article, considering the evaluation of law, Hart observes that: ${ }^{107}$

These requirements and the specific value which conformity with them imparts to laws may be regarded from two different points of view. On the one hand, they maximize the probability that the conduct required by the law will be forthcoming, and on the other hand, they provide individuals whose freedom is limited by the law with certain information and assurances which assist them in planning their lives within the coercive framework of law.

Again, what Hart says in each of these places may be read in different ways; which interpretation is the best is just that - a matter of interpretation.

However, the most stark and unequivocal evidence that Hart held the 'dual value' perspective is Hart's discussion in an encyclopedia entry section on the evaluation of law, in which he observes that conformity to rule of law principles can be seen as valuable from two distinct perspectives - that of the lawgiver and that of the citizen subject to the law. He says that conformity to the requirements of the rule of law should be "regarded from two different points of view": both "maximiz[ing] the probability that the conduct required by the law will be forthcoming" and "provid[ing] individuals whose freedom is limited by the law with certain information and assurances which assist them in planning their lives within the coercive framework of the law". ${ }^{108}$ The requirements of the rule of law are not only instrumental - "the most efficient form of social control" - but are also valuable to the individual liberty through their allowing people to plan their lives. ${ }^{109}$ When we read the other relevant discussions of the rule of law's value against the background of this analysis, the alternative interpretation of Hart becomes the more plausible one: Hart did not seek to deny that conformity to Fuller's principles is of moral value, but instead sought to show that (i) such conformity had a purposive ('efficacy') value for the law-giver, and (ii) such conformity must be adjudged moral according to some acceptable moral principle like liberty or happiness.

105 Hart Punishment and Responsibility, above n 75, at 43-47 and 177-185.

106 Hart Punishment and Responsibility, above n 75, at 47.

107 Hart Essays in Jurisprudence and Philosophy, above n 14, at 114-115.

108 Hart Essays in Jurisprudence and Philosophy, above n 14, at 114-115.

109 At 115 
Again, defenders of the view that Hart denies the moral value of conformity to the rule of law may reply that these statements are ambiguous. Hart is not as clear as he might have been, but what that means for the strength of the alternative interpretation will depend on the view that one takes on the relevant passages, and also on one's wider view about Hart's position, for example whether Hart holds to a strict 'no necessary connection' separation thesis'. ${ }^{110}$ I prefer the view that Hart accepts the rule of law's moral value, although I accept there is ambiguity in his expression of his viewpoint.

In any case, it is incumbent on those who present Hart as denying the moral value of conformity with Fuller's principles to show how they deal with Hart's arguments that run counter to that view. What is needed is an interpretation that makes sense of Hart's stated acceptance of the moral value of Fuller's principles in each of his discussions of the point, in light of the efficacy argument - and I believe that the best way of doing so shows him to accept Fuller's claims of moral value rather than denying them. Recent legal positivists - Raz, Marmor, and Gardner - have also accepted that compliance with Fuller's principles is generally of moral value. ${ }^{111}$

\section{THE IMPACT ON RUNDLE'S PROJECT}

But does it matter for Rundle's purposes - for her argument that Fuller's jurisprudence has been neglected and his challenge not properly answered by positivism? I am not as sure as she is that it does matter. For in comparison with the fact that Hart and positivists who have followed in his tradition have not adequately grappled with Fuller's wider project and his concept of law, the point regarding the rule of law's moral value is relatively insignificant. The fact that Hart arguably agrees with Fuller here, and that other positivists are increasingly minded to agree, means that this is not the flashpoint that it once may have been. Rundle suggests that the positivist lack of understanding of the "value of the rule of law as having two centres of gravity: morality and efficacy" is not only problematic in itself, but also reveals the wider problems with the positivist perspective. ${ }^{112}$ But given the doubt that exists as to the positivists' inability to discern the moral value of the rule of law, showing that this reveals positivism's problems is difficult.

However, this may not matter for Rundle's argument, because it is the wider positivist concept of law itself that is problematic from a Fullerian perspective. In other words, the biggest problem, which

110 For different views on Hart's separation thesis, compare David Dyzenhaus "The Genealogy of Legal Positivism" (2004) 24 OJLS 39 and Matthew Kramer "On the Separability of Law and Morality" (2004) 17 CJLJ 315 with Gardner "Hart on Legality, Justice, and Morality", above n 75; Andrei Marmor "Legal Positivism: Still Descriptive and Morally Neutral" (2006) 26 OJLS 683; Joseph Raz "The Argument from Justice, or How Not to Reply to Legal Positivism" in G Pavlakos (ed) Law, Rights and Discourse (Hart, Oxford, 2007) and Jules Coleman "The Architecture of Jurisprudence" (2011) 121 YLJ 2.

111 Joseph Raz The Authority of Law (2nd ed, Oxford University Press, Oxford, 209) at ch 11; Andrei Marmor "The Rule of Law and its Limits" (2004) 23 Law and Philosophy 1; Gardner "The Legality of Law" above n 75 at $179-181$.

112 Rundle, above n 3, at 108. 
Rundle does identify, is that "many of the questions that Fuller put to Hart in the context of [their] debate were in fact never adequately answered either by Hart or positivists since." 113 But these key questions are not about the moral value of the rule of law. Change the answer to the question of whether compliance with the rule of law is of moral value and nothing of significance is lost by Hart, nor gained by Fuller. Despite the moral value of law being key to the "traditional debate between positivism and natural law", 114 only someone who characterizes Hart and legal positivism in general as painstakingly denying any necessary connection between law and morality would place much weight on this point, and I tend to agree with the view that 'no necessary connection' is not a key Hartian/positivist thesis. ${ }^{115}$ We should therefore move beyond the 'moral' argument framing of the Hart-Fuller debate ${ }^{116}$ not only because the usual way of understanding the debate "obscure[s] the other conversations that are extant in Fuller's jurisprudence", ${ }^{117}$ but also because it is not clear that there is a debate to be had.

So if I am right, and Rundle (and almost everyone else!) is wrong, about what Hart says about the moral value of compliance with rule of law principles, this still does not detract from the main argument of Forms Liberate, which is to show what Fuller's concept of law looks like on its own terms in order to demonstrate that Fuller's projected expressed "a rather different set of challenges to the dominant mode of legal philosophy than those which are ordinarily attributed to it." 118 Rundle's analysis of Fuller's work is not affected by the fact that legal positivists generally accept the rule of law's moral value. For there is still a fundamental divide on what our concept of law is like - on the status of Fuller's rule of law principles as being the conditions that make law possible ${ }^{119}$ - and the consequent implications of that for legal positivism, including the question of the determinants of legal validity.

Even if Hart agrees with the moral value of the rule of law, Fuller's conception of law as intrinsically related to the rule of law may still be the basis for a powerful counterpoint to the positivist perspective; Fuller's challenge to positivism to answer the "question of the conditions of law's existence and the implications of an answer to that question for the positivist defense of the separability thesis"120 are still live and in need of an adequate response. And Rundle's discussions, in

113 At 12 .

114 At 13.

115 See the positions cited above $\mathrm{n} 110$.

116 Rundle, above $\mathrm{n} 3$, at 7 .

117 At 4.

118 Rundle, above n 3, at 12.

119 At 14.

120 At 77. 
the later chapters, of the implications of Fuller's challenge for the thought of contemporary positivists such as Raz and Shapiro show that the Fullerian challenge to Hartian positivism is still powerful, and has still not been adequately met. There is much more yet to be said on this latter question, particularly regarding the varied approaches of the other positivists who have dealt to some degree with Fuller's arguments - Gardner, Kramer, and Marmor - and the discussion that Rundle does provide suggests that she will play a major part in these further discussions.

\section{CONCLUSION}

Fuller's jurisprudential corpus and project can be read in a number of ways, but Rundle's reading of him as set out in Forms Liberate has now become one of the essential aids to reading and understanding Fuller. While there will always be differences in interpretation and emphasis, such as those discussed above, Rundle's detailed analysis provides a clear and cogent elucidation of Fuller's concept of law; its distinctiveness being the emphasis she places on the context of Fuller's eunomics and the placing of his guiding interest of the connection between the form of law and human agency front and centre. The material Rundle draws from Fuller's working notes and correspondence is also an important contribution. Overall, we should be grateful that she has followed Fuller in spending many years reflecting on these issues, in her case over the corpus of Fuller's writings and this additional material, for Forms Liberate gives a coherent and faithful expression of Fuller's thought that will likely provide the firm basis for further engagement and debate concerning the importance of Fullerian anti-positivism for many years to come. 
